\section{Relationship between risk and

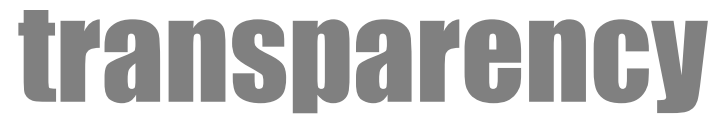 in the financial statements of
professional services entities}

Mirela Elena NICHITA, Bucharest University of Economic Studies, E-mail:mirela.nichita@gmail.com

Marcel VULPOI, Bucharest University of Economic Studies, E-mail: Marcel.Vulpoi@cig.ase.ro

\section{Alstract}

The purpose of financial reports is to provide useful information to users; the utility of information is defined through the qualitative characteristics (fundamental and enhancing). The financial crisis emphasized the limits of financial reporting, which has been unable to prevent investors about the risks they were facing. Due to the current changes in business environment, managers have been highly motivated to rethink and improve the risk governance philosophy, processes and methodologies. The lack of quality, timely data and adequate systems to capture, report and measure the right information across the organization are fundamental challenges to implementing and sustaining all aspects of effective risk management. Starting from '80s, the investors have become more interested in narratives (from the Notes to financial statements), than in primary reports (which disclose financial position and performance). In this research, we aim to identify whether the accounting services entities disclose risk information in their financial statements. The research will use a regression model for the assessment of the relationship between the size, profitability, leverage ratios and risk reporting by the accounting and taxation services providers in Romania during the period 2009-2013.

Keywords: Risk, financial reports, risk management, risk reporting, notes to financial statements.

JEL Classification: M20, M29, M41

To cite this article:

Nichita, M.E. and Vulpoi, M. (2016), Relationship between risk and transparency in the financial statements of professional services entities, Audit Financiar, vol. XIV, no. 5(137)/2016, pp. 540-550, DOI: 10.20869/AUDITF/2016/137/540

Permanent link to this document:

http://dx.doi.org/10.20869/AUDITF/2016/137/540 


\section{Introduction}

Risk has traditionally been defined in terms of the possibility of danger, loss, injury or other adverse consequences (Dionne, 2013; Lupton, 1999). In accounting and finance, risk is considered in terms of decision trees, probability distributions, cost-volumeprofit analysis, discounted cash flow, and capital assets pricing models and hedging techniques. Risk management is the process by which organisations methodically address the risks attaching to their activities in pursuit of organisational objectives and across the portfolio of all their activities (ISO 9001). Effective risk management involves: risk assessment; risk evaluation; risk treatment; and risk reporting. Risk management highlights the fact that the survival of a business entity depends heavily on its capabilities to anticipate and prepare for change rather than waiting for the change and then react to it. It should be clearly understood that the objective of risk management is not to prevent or prohibit risk-taking, but to ensure that the risks are consciously taken with complete knowledge and clear understanding so that it can be measured to help in mitigation.

A key tenet of sound risk management is risk transparency, both in terms of internal risk reporting as well as external disclosure (Lam, 2007). The ability to generate reports much more frequently, every day or even in real-time, would make risk management a much more flexible, powerful and valued tool for business managers.

A survey conducted by The Association of Chartered Certified Accountants (ACCA, 2012) has shown that accountants understand risk and that they believe they make a major contribution to risk management processes. The survey also showed that accountants have a proper understanding of risk.

\section{Literature review}

\subsection{Accounting information quality}

Financial information should be useful for decisionmaking, and this is true when it is relevant and faithfully represents what it purports to represent. The usefulness of financial information is enhanced if it is comparable, verifiable, timely and understandable (International Accounting Standards Board - IASB, 2010). The qualitative characteristics of financial information, as set out in the framework for financial reporting issued by IASB, are fundamental for standard-setting and are intended to be used by firms when they make certain accounting decisions, in particular policy choices and policy changes (IASB, 2010).

\subsection{Quality and transparency}

While "quality" of accounting information and "transparency" of a disclosure system or accounting standards are commonly and interchangeably used terms, a precise definition of quality or transparency that everyone agrees on has been elusive. Pownall and Schipper (1999) define transparency as "standards that reveal the events, transactions, judgments, and estimates underlying the financial statements, and their implications" (Kothari, 2000). Levitt (1998) defines good accounting standards as those that "produce financial statements that report events in the periods in which they occur, not before, and not after." Ball et al. (2000) and Ball et al. (2003) interpret transparency as a combination of the properties of timeliness and conservatism.

Transparency $=f(T, C)$ where:

$$
\begin{aligned}
& \mathrm{T}-\text { Timeliness } \\
& \mathrm{C} \text { - Conservatism }
\end{aligned}
$$

The quality of financial information users receive is a function of both the quality of (accounting) standards governing the disclosure of accounting information and the regulatory enforcement or corporate application of the standards in an economy (Kythreotis, 2014).

Quality of financial information $=f\left(Q_{I F R S}, Q_{G A A P}, M D\right.$, VD)

where:

Q

$Q_{\text {GAAP - quality of local /national accounting standards }}$

MD - mandatory disclosure

VD - voluntary disclosure

Benefits from financial disclosure explain the demand for high quality accounting standards and disclosure systems. The literature shows that both mandated and 
voluntary disclosures reduce information asymmetries among informed and uninformed market participants (Diamond and Verrecchia 1991). Kothari (2000) reminds us that reduced information asymmetry lowers (the information asymmetry component of) the cost of capital by shrinking bid-ask spreads and diminishes stockreturn volatility (Leuz and Verrecchia, 2000).

\subsection{Risk reporting}

Risk disclosure is influenced by the standard setters' requirements through the issuance of accounting standards (IAS 32, IFRS 7, IFRS 8 Financial instruments: disclosure, IFRS 9 Operating segments, IFRS 13 Fair value measurements) underpinning the reporting of risk. In the UK, the Institute of Chartered Accountants in England and Wales (ICAEW) showed an early interest in the subject and issued several documents in order to help companies' directors to identify, manage and measure risk and further enhance their public disclosure by providing more relevant riskrelated information on all types of risk that have a potential bearing upon corporate performance (ICAEW 1997; 1999a, b).

There are two groups of research methods on risk disclosure identified in the literature. The first one is concentrated on the annual report as the source for content analysis of risk disclosure. Methods in the second group are concentrated on the management discussion and analysis (MD\&A) (Amran et al., 2008). The annual reports are the main source of information to examine risk disclosure, the directors prepared it to fulfil with mandatory legal requirements and with accountability function (Linsley and Shrives, 2005). Annual reports now include, in addition to quantitative financial data, narratives, photographs and graphs. Most studies related to risk disclosure are published in: UK (Abraham and Cox, 2007; Dhanani, 2003; latridis, 2008; Linsley and Lawrence, 2007; Linsley and Shrives, 2006; Solomon et al., 2000), Italy ((Beretta and Bozzolan, 2004), Portugal (Lopes and Rodrigues, 2007); Canada (Lajili and Zéghal, 2005); Australia (Poskitt, 2005), USA (Hodder et al., 2001; Jorion, 2002; Linsmeier et al., 2002; Rajgopal, 1999; Schrand, 1997), Romania and Bulgaria (Roman, and Şargu, 2014). In Romania we found an increased interest in risk and risk management (Nichita, 2014), especially related to the financial market (Horobeț and Dumitrescu, 2008; Horobeț and Ilie, 2009).
Hodder et al. (2001) reached the following conclusions based on the analysis of Securities and Exchange Commission - SEC document Financial Risk Release (FRR No. 48):

1. Disclosure requirements do not ask for a high volume of quantitative information to help investors and users to understand the companies' instruments for risk disclosures.

2. The risk assessment process is a very difficult matter for users and investors.

3. Users of financial statement who are not familiar with the FRR No.48 do not have alternatives by which to understand risk information.

Linsley and Shrives (2000) examined risk reporting requirements within an examination of advantages and disadvantages of disclosure of risk information through annual reports and arrived to the conclusion that entities can reduce the cost of capital by improving the quality of information disclosed to the users of accounting information. Also, they encouraged firms to disclose more forward-looking information to raise the investors' value. Dietrich et al. (2001) also focused on the value of disclosing forward-looking information within annual reports, considering its positive effects on improving market efficiency. Botosan (2004) explained the difficulties of measuring the quality of risk disclosures: the quality of disclosure depends on user perceptions. The most important study was realised by Linsley and Shrives (2006), who examined narrative risk disclosure in the annual reports for 79 non-financial UK companies. They collected risk information referring to:

- Three narrative groups (upside/downside, monetary/non-monetary and past/future),

- Six risk factors (financial, operational, empowerment, information processing and technology, integrity and strategy).

They found a positive association between narrative risk reporting (number of risk disclosures) and company size. The same relationship was confirmed in the study by Beretta and Bozzolan (2004) for Italian companies. Linsley and Shrives (2006) did not find any correlation between risk reporting in the notes to the financial statements (number of risk disclosures) and the five analysed measures of risk: gearing ratio, asset cover, price to book value of equity, qui-score and beta-factor. 


\section{Methodology and sample}

The research analyses the relationship between company size, financial and economic profitability and risk reporting, using the regression model. The selection of companies in the sample was based on the availability of data. The study excluded financial and insurance firms because they are subject to specific disclosure requirements, so their annual reports cannot be considered as voluntarily determined. The source of the data sample is doingbusiness.ro. The study is based on a sample of 25 companies, classified by doingbusiness.ro as large companies; the doingbusiness.ro website uses the Ernst \& Young (E\&Y) methodology in order to classify entities into small, medium-sized and large. The formula proposed by E\&Y includes quantitative and qualitative variables. The Romanian accounting services market is in the amount of approximately EUR 400 mil. (Vulpoi, 2014).

Our research is focused on risk reporting performed by a professional accountant in their financial statements: since they prepare other entities' financial statements, we consider as appropriate to examine if and how they report risk for their companies. The first part of research is a qualitative research (literature review used to define the theoretical framework). Based on published financial statements, especially the notes to financial statement or audit reports, we performed a content analysis and searched for the term "risk" in order to determine if the professional accountants reported the risks that they are confronting. We used an in-depth analysis to detect the presence of the related terms: credit risk, market risk, exchange rate risk, strategic risk, operational risk.

If the companies are audited, their financial statements (and therefore the notes to financial statements) include more aspects related to risk than other companies'. Generally, the risks disclosed is are related to financial risk (exchange rate risk, credit risk, market risk); there are very few aspects about strategically or operational risk in the financial statements of accounting professional services providers. We determined that the providers of financial services (accounting and taxation) do not use financial instruments.

For the quantitative analysis of risk reporting, we used a regression model with five variables, as it follows:

$$
\begin{gathered}
\text { Risk disclosure }(R D)=\beta_{0}+\beta_{1} \text { Firm Size }+\beta_{2} \text { Leverage } \\
+\beta_{3} \text { Profitability (based on assets) }+\beta_{4} \text { Profitability } \\
\text { (based on equity) }+\beta_{5} \text { Audit }+\mathcal{E}
\end{gathered}
$$

\section{Table 1. Measurement of variables}

\begin{tabular}{|l|l|}
\hline \multicolumn{1}{|c|}{ Independent variables } & \multicolumn{1}{c|}{ Measurement } \\
\hline 1 - Firm size & Natural logarithm of turnover at the end of period. \\
\hline 2 - Leverage & Total debt (liabilities) to equity ratio. \\
\hline 3 - Profitability & Return on total assets. \\
\hline 4 - Profitability & Return on equity. \\
\hline 5 - Audit firm size & $\begin{array}{l}\text { Dummy variable - is assigned the value } 1 \text { if the financial statements of the company are audited } \\
\text { by a Big } 4 \text { firm, and the value } 0 \text { if otherwise (not audited or audited by a non-Big 4). }\end{array}$ \\
\hline
\end{tabular}

Source: Authors' projections

The results of the regression analysis are presented at the end of paper (Appendix).

\section{Resulits analysis and perspectives for future research}

The data on risk disclosure levels was obtained from the annual financial statements and audit reports issued during $2009-2013$. The variables and their possible effects on the model are explained below:

- Turnover is used as proxy for company size: based on the fact that professional (accounting and taxation) services companies have less assets than others (manufacturing), turnover may be a reliable indicator of size. The fact that large companies have greater financing needs, means they provide more information about risk. 
- Leverage is computed as the ratio between total debts, divided by total assets of the company. A high level of leverage indicates increased company risk.

- Profitability is represented by two indicators: return on assets and return on equity. The major companies have a motivation to disclose higher amounts of risk information to increase investors' confidence and decrease political sensitivity.

- Audit: we consider that is important to know if the companies in the sample are audited or not; if the financial statements are audited by a Big 4 company, the variable is assigned the value one (1). If the financial statements are audited by a non-Big 4 company or are not audited, the variable is assigned the value zero (0).

\subsection{Descriptive analysis results}

Appendix 1 shows the results related to the descriptive analysis of the sample for the period 2009-2013. The turnover (natural logarithm) varies from approximate values of 16 to 18 for the entire analysed period. The profitability indicators (rates of return) display negative values when there is a loss in the financial year. Generally, companies in the accounting services providers sector included in the sample have positive results in the analysed period (retained earnings) (92\%).

\subsection{Multiple regression analysis results}

- Company size is positively associated with risk disclosure $\left(P_{2009}, P_{2010}, P_{2011}, P_{2012}\right.$, and $P_{2013}$ are less than $5 \%$ ). These results confirm the findings from the related literature (Beattie et al., 2004, Firth, 1979).

The companies from our sample are major companies and they present risk information in the notes to financial statement in accordance with the principle Tone from the top.

- Leverage is a measure that must be correlated with risk reporting. The indicator recorded positive values in in 2009, 2010 and 2013 negative values in 201 and 2012. This phenomenon may be explained by the fact that the companies in the sample are not listed on the stock exchange and therefore there are no compulsory reporting requirements and the debtors share private information between them.

- Profitability is expressed in terms of return on assets and return on equity and it has a relatively constant influence on risk reporting. It is noticed the significantly negative effect of return on assets in 2012, when the entities reported very low results, which determined values of less than $0.01 \%$ for this indicator.

- Audit. The fact that some entities in the sample are audited has resulted in more careful risk reporting. However, starting with 2011, the effect of audit on the quality of risk reporting has diminished.

Risk is not always bad for business and there is a real need to develop a bigger picture of risk management, one that balances risks and opportunities. Organizations have increasingly come to recognize the opportunistic side and the value-creating potential of risk. Risk-taking is necessary for economic growth and success, and the new risk management approach should re-embrace risk as a source of advantages. Essentially, there is a realization that risk should not be completely avoided and, in fact, informed risk-taking is a means to competitive advantage (Casualty Actuarial Society, 2003).

\section{Conclusions}

The focus of good risk management is the identification and treatment of those risks which lead to the standardization of risk treatments within an organization.

As accountants provide support for decision-making, this approach to risk management puts accountants in a very important position. Most "risky" decisions in companies have some sort of financial aspect, and it is most often the accountants who are asked to estimate the financial implications of alternative courses of action. In addition, accountants will almost always outnumber the formally designated risk managers in any given organisation. Accountants provide objective measurement, analysis and assurance for making good decisions. Good decisions mean less risk. As accountants share an aptitude for managing risk, it makes sense to look at how the day-to-day activities of the average accountant contribute to risk management.

The benefits of improved risk reporting should not be seen as being purely limited to individual investors or to the managers who gain investors' confidence by such reporting. There are potential economic benefits to the wider community in terms of better risk-based resource allocation, with increased long-term capital formation as 
a result. The need to report on risks and risk management can also be expected to lead to improved internal information being collected on the risks that the enterprise faces, as well as the need to demonstrate that the risks identified are being managed, as stakeholders hold directors accountable for risk management.

However, companies' directors are sometimes reluctant to disclose additional information because competitors may make strategic use of the disclosed information to their advantage (Linsley and Shrives, 2005). This may lead to the imposition of a proprietary cost, hence putting a company at a competitive disadvantage and affecting the company negatively.

Entities need to integrate the risk-taking and the risk controlling sides into their strategies and involve all the different views and perspectives within the organization (business executives, heads of business lines, risk managers) as well as including into the equation the perceptions of stakeholders, customers, regulators and other external parties. To accomplish both objectiveslinking better risk and strategy, on the one hand, and integrating the risk-taking and the risk management sides, on the other hand - companies need to adopt a fundamentally different approach. The first step of this approach is to articulate a plausible future state, linked to the different strategic initiatives that have already been agreed. The plausible future state is directly derived from explicit assumptions made by the top management about the future. Making very explicit what are the possible threats and opportunities allows to management to identify risks in the context of their strategy and the possible opportunities (Maurer, 2009).

\section{REFERENCES}

1. Abraham, S. and Cox, P. (2007) Analysing the determinants of narrative risk information in UK FTSE 100 annual reports, The British Accounting Review, vol. 39, no. 3, pp. 227-248, DOl: 10.1016/j.bar.2007.06.002.

2. ACCA - The Association of Chartered Certified Accountants (2012), Accountants for business. Rules for risk management: culture, behaviour and the role of accountants, [pdf]. Available at http://www.accaglobal.com/content/dam/acca/glob al/PDF-technical/corporate-governance/tech-afbrrm_exec2.pdf [Accessed on April 2, 2016].

3. Amran, A., Bin, A.M.R. and Hassan, B.C.H.M. (2008), Risk reporting. An exploratory study on risk management disclosure in Malaysian annual reports, Managerial Auditing Journal, vol. 24, no. 1, pp. 39-57, DOI:10.1108/02686900910919893.

4. Ball, R., Kothari S. and Robin, A. (2000), The Effect of International Institutional Factors on Properties of Accounting Earnings, Journal of Accounting \& Economics, vol. 29, no. 1, pp. 1-51, DOI:10.1016/S0165-4101(00)00012-4.

5. Ball, R., Robin, A. and Wu, J. (2003), Incentives versus standards: properties of accounting income in four East Asian countries, Journal of Accounting and Economics, vol. 36, pp. 235-270, DOI:10.1016/j.jacceco.2003.10.003.
6. Beattie, V., Mclnnes, W. and Fearnley, S. (2004), A methodology for analysing and evaluating narratives in annual reports: a comprehensive descriptive profile and metrics for disclosure quality attributes, Accounting Forum, vol. 28, no. 3, pp. 205-236, DOI: 10.1016/j.accfor.2004.07.001.

7. Beretta, S. and Bozzolan, S. (2004), A framework for the analysis of firm risk communication, The International Journal of Accounting, vol. 39, no. 3, pp. 265-288, DOI: 10.1016/j.intacc.2004.06.006.

8. Botosan, C.A. (2004), Discussion of a framework for the analysis of firm risk communication, The International Journal of Accounting, vol. 39, no. 3, pp. 289-295, DOI: 10.1016/j.intacc.2004.06.007.

9. Casualty Actuarial Society-Enterprise Risk Management Committee (2003), Overview of Enterprise Risk Management, [pdf]. Available at: https://erm.ncsu.edu/az/erm/i/chan/marticles/documents/CasualtyActuarialSocietyOvervi ewofERM.pdf [Accessed on April 2, 2016].

10. Dhanani, A. (2003). Foreign exchange risk management: a case in the mining industry. The British Accounting Review, vol. 35, no. 1, pp. 3563, DOI: $10.1016 / \mathrm{s} 0890-8389(03) 00002-7$.

11. Diamond, D. and Verrecchia, R. (1991), Disclosure, Liquidity, and the Cost of Capital, 
Journal of Finance, vol. 46, no. 4, pp. 1325-1360, DOI: $10.2307 / 2328861$

12. Dietrich, J.R., Kachelmeier, S.J., Kleinmuntz, D.N. and Linsmeier, T.J. (2001), Market efficiency, bounded rationality, and supplemental business reporting disclosures, Journal of Accounting Research, vol. 39, no. 2, pp. 243-268, Stable URL: http://www.jstor.org/stable/2672955.

13. Dionne, G. (2013), Risk management: History, definition and critique, Risk Management and Insurance Review, vol. 16, no. 2, pp. 147-166, DOI: 10.1111/rmir.12016.

14. E\&Y (2012), Ranking methodology for Major Companies in Romania, [online]. Available at: http://mcr.doingbusiness.ro/articles/rankingmethodology-for-major-companies-inromania/2583 [Accessed on April 2, 2016].

15. Firth, M. (1979), The impact of size, stock market listing, and auditors on voluntary disclosure in corporate annual reports, Accounting and Business Research, vol. 9, no. 36, pp. 273-280, DOl: 10.1080/00014788.1979.9729168.

16. Hodder, L., Koonce, L. and McAnally, M.L. (2001), SEC market risk disclosures: Implications for judgment and decision making, Accounting Horizons, vol. 15, no. 1, pp. 49-70, DOl: 10.2308/acch.2001.15.1.49.

17. Horobet, A. and Dumitrescu S. (2008), Insights into Central and Eastern European countries competitiveness: on the exposure of capital markets to exchange rate risk, Review of Economic and Business Studies, vol. 1, no. 2, pp. 107-126.

18. Horobet, A. and llie L. (2009), On the exchange rate risk contribution to the performance of international investments: the case of Romania, Review of Economic and Business Studies, vol. 1, no. 2, pp. $57-85$.

19. IASB (2010), The Conceptual Framework for Financial Reporting 2010, [pdf] Available at: http://www.ifrs.org/News/Press-

Releases/Documents/ConceptualFW2010vb.pdf, [Accessed on April 2, 2016].

20. IASB (2016), 2016 IFRS Standards (Red Book), London: IFRS Foundation.

21. latridis, G. (2008), Accounting disclosure and firms' financial attributes: Evidence from the UK stock market, International Review of Financial Analysis, vol. 17, no. 2, pp. 219-241, DOl:

10.1016/j.irfa.2006.05.003.

22. ICAEW (1997), Financial Reporting of Risk: Proposals for a Statement of Business Risk, London: ICAEW, 1997.

23. ICAEW (1999a), Turnbull Report, [online]. Available at: http://www.icaew.com/en/ library/subject-gateways/corporategovernance/codes-and-reports/turnbull-report [Accessed on April 2, 2016].

24. ICAEW (1999b), No surprises: the case for better risk reporting, [online] Available at: https://www. deepdyve.com/lp/emerald-publishing/no-surprisesthe-case-for-better-risk-reporting-M8Z278swYc, [Accessed on April 2, 2016].

25. International Organization for Standardization (2015), ISO 9001:2015 Quality management systems - Requirements, [online]. Available at: http://www.iso.org/iso/home/store/catalogue_tc/cat alogue_detail.htm?csnumber $=62085$ [Accessed on April 2, 2016].

26. International Organization for Standardization (2009), ISO 31000:2009 Risk Management Principles and Guidelines, [online]. Available at: http://www.iso.org/iso/catalogue_detail.htm?csnum ber=43170 [Accessed on April 2, 2016].

27. Jorion, P. (2002), How Informative Are Value-atRisk Disclosures? Accounting Review, vol. 77, no. 4, pp. 911-931, DOI: 10.2308/accr.2002.77.4.911.

28. Kothari, S.P. (2000), The role of financial reporting in reducing financial risks in the market, [pdf] Available at: http://www.bostonfed.org/economicl conf/conf44/cf44_6.pdf, [Accessed on April 2, 2016].

29. Kythreotis, A. (2014), Measurement of Financial Reporting Quality Based on IFRS Conceptual Framework's Fundamental Qualitative Characteristics, European Journal of Accounting, Finance and Business, vol. 2, no. 3, pp. 4-29.

30. Lajili, K. and Zéghal, D. (2005), A content analysis of risk management disclosures in Canadian annual reports, Canadian Journal of Administrative Sciences/Revue Canadienne des Sciences de I'Administration, vol. 22, no. 2, pp. 125-142, DOI: 10.1111/j.1936-4490.2005.tb00714.x. 
31. Lam, J. (2007) Enterprise Risk Management at Asian Banks: From Challenges to Strategies, Executive White Paper, Asia Risk Management Institute (ARMI) [pdf] Available at: http://www. jameslam.com/images/PDF/ARMI\%20White\%20P aper\%20Final.pdf, [Accessed on April 2, 2016].

32. Leuz, C. and Verrecchia, R. (2000), The Economic Consequences of Increased Disclosure, Journal of Accounting Research, vol. 38 (suplimentar), pp. 91-124, DOI: 10.2307/2672910.

33. Levitt, A. (1998), The Importance of High Quality Accounting Standards, Accounting Horizons vol. 12, no. 1, pp. 79-82.

34. Linsley, P. M. and Lawrence, M. J. (2007), Risk reporting by the largest UK companies: readability and lack of obfuscation, Accounting, Auditing \& Accountability Journal, vol. 20, no. 4, pp. 620-627, DOI: $10.1108 / 09513570710762601$.

35. Linsley, P.M. and Shrives, P.J. (2005), Examining risk reporting in UK public companies. The Journal of Risk Finance, vol. 6, no. 4, pp. 292-305, DOI: $10.1108 / 15265940510613633$.

36. Linsley, P.M. and Shrives, P.J. (2006) Risk reporting: A study of risk disclosures in the annual reports of UK companies, The British Accounting Review, vol. 38, no. 4, pp. 387-404, DOI: 10.1016/j.bar.2006.05.002.

37. Linsmeier, T.J., Thornton, D.B., Venkatachalam, M. and Welker, M. (2002), The effect of mandated market risk disclosures on trading volume sensitivity to interest rate, exchange rate, and commodity price movements, Accounting Review, vol. 77, no. 2, pp. 343-377, Stable URL: http://www.jstor.org/stable/3068901.

38. Lopes, P.T. and Rodrigues, L.L. (2007), Accounting for financial instruments: An analysis of the determinants of disclosure in the Portuguese Stock Exchange, The International Journal of Accounting, vol. 42, no. 1, pp. 25-56, DOI:10.1016/j.intacc.2006.12.002.

39. Lupton D. (1999), Risk, London: Routledge.

40. Maurer F. (2009), Creating Value through Enterprise Risk Management, The Journal of Applied Business Research, vol. 25, no. 3, pp. 13-24, DOI:10.19030/jabr.v25i3.1023

41. Nichita, M. (2015) Empirical research regarding risk and risk management in Romanian journals, AAU Conference, Prague, Proceedings of the $2^{\text {nd }}$ International Conference, [pdf] Available at:
http://car.aauni.edu/wp-content/uploads/IRFSProceedings_2014-Published.pdf, [Accessed on April 2, 2016].

42. Poskitt, R. (2005), Disclosure regulation and information risk, Accounting \& Finance, vol. 45, no. 3, pp. 457-477, DOI: 10.1111/j.1467629X.2005.00147.x.

43. Pownall, G. and Schipper, K. (1999), Implications of Accounting Research for the SEC's Consideration of International Accounting Standards for U.S. Securities Offerings, Accounting Horizons vol. 13, no. 3, pp. 259-280, DOI: 10.2308/acch.1999.13.3.259.

44. Rajgopal, S. (1999), Early evidence on the informativeness of the SEC's market risk disclosures: The case of commodity price risk exposure of oil and gas producers, Accounting Review, vol. 74, no. 3, pp.251- 280, Stable URL: http://www.jstor.org/stable/248488.

45. Roman, A. and Şargu, A.C. (2014), Bank liquidity risk analysis in the new European Union member countries: Evidence from Bulgaria and Romania, Procedia Economics and Finance, vol. 15, pp. 556576, DOI: 10.1016/S2212-5671(14)00512-7.

46. Schrand, C. M. (1997), The association between stock-price interest rate sensitivity and disclosures about derivative instruments, Accounting Review, vol. 72, no. 1, pp. 87-109, Stable URL: http://www.jstor.org/stable/248224.

47. SEC (1997), Financial Reporting Release No. 48 Disclosure of accounting policies for derivative financial instruments and derivative commodity instruments and disclosure of quantitative and qualitative information about market risk inherent in derivative financial instruments, other financial instruments, and derivative commodity instruments, Washington, DC: Securities and Exchange Commission.

48. Solomon, J.F., Solomon, A., Norton, S.D. and Joseph, N.L. (2000), A conceptual framework for corporate risk disclosure emerging from the agenda for corporate governance reform, The British Accounting Review, vol. 32, no. 4, pp. 447478, DOI: $10.1006 /$ bare.2000.0145.

49. Vulpoi, M. (2014), Keep calm and hire a consultant, Interviu Bizmaker, [online], Available at: http://bizmaker.ro/interviuri/378-marcel-vulpoidirector-general-vulpoi-toader-management-keppcalm-and-hire-a-consultant [Accessed on April 2, 2016]. 


\section{Appendix 1. The summary of characteristics of sample}

\begin{tabular}{|l|l|r|r|r|r|r|r|r|}
\hline Year & Variables & \multicolumn{1}{l}{ Min. } & \multicolumn{1}{l}{ Mean } & \multicolumn{1}{l}{ SD } & \multicolumn{1}{l}{ 1st quartile } & \multicolumn{1}{l}{ Median } & \multicolumn{1}{l|}{ 3rd $^{\text {quartile }}$} & \multicolumn{1}{l}{ Max. } \\
\hline $\mathbf{2 0 0 9}$ & Turnover & 11.3674 & 16.0665 & 1.675845 & 15.3778 & 15.9242 & 17.2328 & 18.6842 \\
\hline & Leverage & 0.0000 & 28.8036 & 79.5725 & 0.1204 & 10.0370 & 20.1150 & 401.6522 \\
\hline & ROA & -0.7800 & 0.2631 & 0.372745 & 0.0265 & 0.3128 & 0.4671 & 0.9616 \\
\hline & ROE & 0.0000 & 0.7652 & 0.488175 & 0.4743 & 0.7480 & 1.1297 & 1.8287 \\
\hline $\mathbf{2 0 1 0}$ & Turnover & 13.4643 & 16.2494 & 1.3078 & 15.3269 & 16.0168 & 17.3756 & 18.6449 \\
\hline & Leverage & 0.0000 & 14.5414 & 19.7798 & 0.2082 & 11.6936 & 15.2578 & 69.7800 \\
\hline & ROA & -0.1608 & 0.2371 & 0.2589 & 0.0391 & 0.2098 & 0.4037 & 0.9472 \\
\hline & ROE & -2.0301 & 0.5391 & 0.7027 & 0.1794 & 0.5698 & 1.0881 & 1.4045 \\
\hline $\mathbf{2 0 1 1}$ & Turnover & 14.0213 & 16.3267 & 1.2699 & 15.5078 & 16.0166 & 17.4546 & 18.5120 \\
\hline & Leverage & 0.0000 & 9.0751 & 14.8702 & 0.2054 & 0.6238 & 13.1790 & 57.9050 \\
\hline & ROA & -0.0680 & 0.2155 & 0.2146 & 0.0095 & 0.1918 & 0.3340 & 0.6422 \\
\hline & ROE & -0.4844 & 0.4033 & 0.4087 & 0.1054 & 0.3301 & 0.7333 & 1.1757 \\
\hline $\mathbf{2 0 1 2}$ & Turnover & 14.3398 & 16.2545 & 1.1370 & 15.5725 & 15.9489 & 16.9326 & 18.5725 \\
\hline & Leverage & 0.0000 & 8.3083 & 14.023339 & 0.0000 & 0.4309 & 10.6750 & 50.4610 \\
\hline & ROA & -0.0702 & 0.1702 & 0.2309 & 0.0000 & 0.0720 & 0.3295 & 0.8720 \\
\hline & ROE & -1.4844 & 0.5164 & 1.6801 & 0.0000 & 0.1325 & 0.5275 & 8.1862 \\
\hline $\mathbf{2 0 1 3}$ & Turnover & 14.1875 & 16.5070 & 1.1956 & 15.8162 & 16.2651 & 17.5516 & 18.5672 \\
\hline & Leverage & 0.0000 & 14.2001 & 24.3246 & 0.3518 & 0.8348 & 14.6270 & 96.8940 \\
\hline & ROA & -0.3494 & 0.2387 & 0.2827 & 0.0600 & 0.2028 & 0.3796 & 0.8872 \\
\hline & ROE & -0.5846 & 0.5847 & 0.5330 & 0.2026 & 0.5214 & 0.9387 & 1.8348 \\
\hline
\end{tabular}

Turnover* - In Turnover

SD - Standard deviation

\begin{tabular}{|l|r|}
\hline Appendix 2 \\
\hline \multicolumn{2}{|c|}{ Year 2009 } \\
\hline REGRESSION STATISTICS \\
\hline Multiple R & 0.892666813 \\
\hline R Square & 0.796854039 \\
\hline Adjusted R Square & 0.743394576 \\
\hline Standard Error & 3.275465277 \\
\hline Observations & 25 \\
\hline
\end{tabular}

\begin{tabular}{|l|r|r|r|r|r|}
\hline \multicolumn{1}{|c|}{ ANOVA } & \multicolumn{1}{c|}{ df } & \multicolumn{1}{c|}{ SS } & \multicolumn{1}{c|}{ MS } & \multicolumn{1}{c|}{ F } & Significance $\mathbf{F}$ \\
\hline Regression & 5 & 799.5952172 & 159.9190434 & 14.90576204 & $0.00052 \%$ \\
\hline Residual & 19 & 203.8447828 & 10.72867278 & & \\
\hline Total & 24 & $1,003.44$ & & & \\
\hline
\end{tabular}




\begin{tabular}{|l|r|}
\hline Year 2010 \\
\hline REGRESSION STATISTICS \\
\hline Multiple R & 0.8959909 \\
\hline R Square & 0.8027998 \\
\hline Adjusted R Square & 0.7509050 \\
\hline Standard Error & 3.2271756 \\
\hline Observations & 25 \\
\hline
\end{tabular}

\begin{tabular}{|l|r|r|l|l|r|}
\hline \multicolumn{1}{|c|}{ ANOVA } & \multicolumn{1}{c|}{ df } & \multicolumn{1}{c|}{ SS } & MS & F & Significance $\mathbf{F}$ \\
\hline Regression & 5 & 805.5614132 & 161.1122826 & 15.46975557 & $0.0004 \%$ \\
\hline Residual & 19 & 197.8785868 & 10.41466247 & & \\
\hline Total & 24 & $1,003.44$ & & & \\
\hline
\end{tabular}

\begin{tabular}{|l|r|}
\hline \multicolumn{2}{|l|}{ Year 2011} \\
\hline REGRESSION STATISTICS \\
\hline Multiple R & 0.592941723 \\
\hline R Square & 0.351579886 \\
\hline Adjusted R Square & 0.180943014 \\
\hline Standard Error & 5.851903329 \\
\hline Observations & 25 \\
\hline
\end{tabular}

\begin{tabular}{|l|r|r|r|r|r|}
\hline \multicolumn{1}{|c|}{ ANOVA } & \multicolumn{1}{c|}{ df } & \multicolumn{1}{c|}{ SS } & \multicolumn{1}{c|}{ MS } & F & Significance $\mathbf{F}$ \\
\hline Regression & 5 & 352.7893212 & 70.55786424 & 2.060398097 & $11.5659 \%$ \\
\hline Residual & 19 & 650.6506788 & 34.24477257 & & \\
\hline Total & 24 & $1,003.44$ & & & \\
\hline
\end{tabular}

\begin{tabular}{|l|r|}
\hline \multicolumn{2}{|l|}{ Year 2012 } \\
\hline REGRESSION STATISTICS \\
\hline Multiple R & 0.677722767 \\
\hline R Square & 0.459308149 \\
\hline Adjusted R Square & 0.317020820 \\
\hline Standard Error & 5.343721506 \\
\hline Observations & 25 \\
\hline
\end{tabular}

\begin{tabular}{|l|r|r|c|c|r|}
\hline \multicolumn{1}{|c|}{ ANOVA } & \multicolumn{1}{c|}{ df } & \multicolumn{1}{c|}{ SS } & MS & F & Significance $\mathbf{F}$ \\
\hline Regression & 5 & 460.8881689 & 92.17763378 & 3.228032681 & $2.81789 \%$ \\
\hline Residual & 19 & 542.5518311 & 28.55535953 & & \\
\hline Total & 24 & $1,003.44$ & & & \\
\hline
\end{tabular}

\begin{tabular}{|l|r|}
\hline \multicolumn{2}{|l|}{ Year $\mathbf{2 0 1 3}$} \\
\hline REGRESSION STATISTICS \\
\hline Multiple R & 0.65217312 \\
\hline R Square & 0.42532978 \\
\hline Adjusted R Square & 0.27410077 \\
\hline Standard Error & 5.50906949 \\
\hline Observations & 25 \\
\hline
\end{tabular}




\begin{tabular}{|l|r|r|r|r|r|}
\hline \multicolumn{1}{|c|}{ ANOVA } & df & \multicolumn{1}{c|}{ SS } & \multicolumn{1}{c|}{ MS } & F & Significance $\mathbf{F}$ \\
\hline Regression & 5 & 426.7929128 & 85.35858256 & 2.812488096 & $4.58469 \%$ \\
\hline Residual & 19 & 576.6470872 & 30.3498467 & & \\
\hline Total & 24 & $1,003.44$ & & & \\
\hline
\end{tabular}

\begin{tabular}{|c|c|c|c|c|}
\hline Year 2009 & Coefficients & Standard Error & t Stat & P-value \\
\hline Intercept & 0.285816503 & 6.891178757 & 0.041475706 & 0.967349411 \\
\hline Company size (turnover) & -0.097344415 & 0.456290687 & -0.213338596 & 0.83333535 \\
\hline Leverage & 0.005605557 & 0.008983964 & 0.62395141 & 0.540079312 \\
\hline Return on Assets (ROA) & 2.933872774 & 2.038614384 & 1.439150434 & 0.166379636 \\
\hline Return on Equity (ROE) & 2.02922395 & 1.51045124 & 1.34345545 & 0.194951412 \\
\hline
\end{tabular}

\begin{tabular}{|l|c|c|c|c|}
\hline \multicolumn{1}{|c|}{ Year 2010 } & Coefficients & Standard Error & $\boldsymbol{t}$ Stat & P-value \\
\hline Intercept & -9.884350135 & 9.317803922 & -1.060802547 & 0.302078778 \\
\hline Company size & 0.609891154 & 0.587940141 & 1.037335455 & 0.312601961 \\
\hline Leverage & 0.078012268 & 0.038805812 & 2.010324325 & 0.058809559 \\
\hline Return on Assets (ROA) & 2.334120525 & 3.457292009 & 0.675129702 & 0.507726889 \\
\hline Return on Equity (ROE) & 0.417395143 & 1.329577618 & 0.313930633 & 0.756994411 \\
\hline
\end{tabular}

\begin{tabular}{|l|c|c|c|c|}
\hline \multicolumn{1}{|c|}{ Year 2011 } & Coefficients & Standard Error & $\boldsymbol{t}$ Stat & P-value \\
\hline Intercept & -23.77139202 & 18.01856888 & -1.319271923 & 0.202756882 \\
\hline Company size & 1.928979739 & 1.142125965 & 1.688937821 & 0.107575711 \\
\hline Leverage & -0.07097518 & 0.094740671 & -0.749152179 & 0.462940367 \\
\hline Return on Assets (ROA) & -2.859570128 & 11.76646531 & -0.243027116 & 0.810588775 \\
\hline Return on Equity (ROE) & -2.634309791 & 6.406433045 & -0.411197584 & 0.685528617 \\
\hline
\end{tabular}

\begin{tabular}{|l|c|c|c|c|}
\hline \multicolumn{1}{|c|}{ Year 2012 } & Coefficients & Standard Error & t Stat & P-value \\
\hline Intercept & -48.90183973 & 26.36790015 & -1.854597425 & 0.079241022 \\
\hline Company size & 3.589122307 & 1.718595092 & 2.088404839 & 0.050458717 \\
\hline Leverage & -0.133053472 & 0.101998519 & -1.304464738 & 0.207656172 \\
\hline Return on Assets (ROA) & -8.678798552 & 6.39926167 & -1.356218733 & 0.190928946 \\
\hline Return on Equity (ROE) & 0.400004558 & 0.78161588 & 0.51176616 & 0.614711454 \\
\hline
\end{tabular}

\begin{tabular}{|l|r|r|r|c|}
\hline \multicolumn{1}{|c|}{ Year 2013 } & Coefficients & Standard Error & \multicolumn{1}{c|}{$\mathrm{t}$ Stat } & P-value \\
\hline Intercept & -36.54948469 & 20.69964506 & -1.765705865 & 0.093510664 \\
\hline Company size & 2.633023728 & 1.278803564 & 2.058974343 & 0.053471783 \\
\hline Leverage & 0.023375972 & 0.051052361 & 0.457882293 & 0.652230251 \\
\hline Return on Assets (ROA) & -2.023800499 & 4.642690241 & -0.435911162 & 0.667813624 \\
\hline Return on Equity (ROE) & 0.255581758 & 2.341778793 & 0.109140009 & 0.914235879 \\
\hline
\end{tabular}

